\title{
Regeneration Status of Mangrove Forests in Mida Creek, Kenya: A Compromised or Secured Future?
}

\begin{abstract}
The structure and regeneration patterns of Mida Creek mangrove vegetation were studied along belt transects at 2 forest sites of Mida Creek ( $\left.3^{\circ} 20^{\prime} \mathrm{S}, 40^{\circ} 00^{\prime} \mathrm{E}\right)$ : Uyombo and Kirepwe. Based on the species importance values, the dominant mangrove tree species in Mida were Ceriops tagal (Perr.) C. B. Robinson and Rhizophora mucronata Lamk. Tree density varied from 1197 trees $\mathrm{ha}^{-1}$ at Kirepwe to 1585 trees ha-1 at Uyombo and mean tree height was higher at the former site compared to the latter. The sizeclass structure at both localities of Mida showed the presence of more small trees than large ones. Spatial distribution pattern of adults and juveniles varied greatly between sites and they showed a close to uniform pattern (Morisita's Index $\mathrm{I}_{0}<1$ ) for trees, but a tendency to random distribution $\left(l_{0}=1\right)$ for juveniles. The present paper shows that unmanaged but exploited mangroves do not necessarily disappear, but change qualitatively from locally preferred $R$. mucronata to the less preferred $C$. tagal. Whereas the effects of this change on the ecological function of the mangrove cannot be estimated yet, the economical function of the mangrove has evidently weakened.
\end{abstract}

\section{INTRODUCTION}

Mangrove forests in Kenya have traditionally been used as a source of building poles and firewood (1-3). About $70 \%$ of the population along the Kenyan coast depend on mangrove poles for house construction (4), and the recent boom in tourism in the area over the last few decades has led to an increasing demand for mangrove poles for construction of restaurants, hotels and holiday resorts (5).

The most harvested mangrove poles are the mazio and boriti sized poles with butt diameter ranging from 8.0 to $13 \mathrm{~cm}$. These are used in construction $(2,3,6)$. Larger poles of banaa (diameter above $30.5 \mathrm{~cm}$ ) are of less economic value and are left standing in the forest $(3,7,8)$. Excessive removal of boriti and mazio poles has created complex mangrove management problems in Kenya along the whole coast $(3,5,6)$. The overgrowing banaa canopy shade out juveniles and young trees and cause them to be crooked, as they grow according to available space in the closed forest canopy (9).

In order to achieve sustainable forest management there is a need to assess the trends in forest conditions over time. One way to characterize mangrove ecosystem, and to monitor changes is through the assessment of forest structure $(10,11)$, these aspects being closely linked to forest productivity (12). Some of the structural parameters used are: tree height, stem diameter, basal area, crown diameter and leaf area index $(11,13)$, from which other attributes like stand tables, regeneration rates, distribution patterns and complexity index can be derived. Structural studies have been used to describe the mangroves of Puerto Rico (14), and mangrove stands in Florida, Mexico and Costa Rica (15) among others.

Past studies on mangrove forestry in Kenya tend to have concentrated on floristic composition and distribution of species (16-
18), economic utilization $(2,3)$ and regeneration strategies of the principal species $(6,19)$. Work on mangrove benthos has yielded results regarding resource partitioning $(20)$, zonation $(21,22)$, feeding habits and propagule predation (23-26). Studies on nutrient cycling have also been carried out $(27,28)$. Quantitative data on mangrove vegetation structure, stocking rates and yield sustainability is lacking, an aspect which has been much neglected until recently for want of resources and personnel.

The main objective of the present study was to investigate natural regeneration and timber potential of the mangrove forests of Mida Creek for better management, based on the principle of sustained yield.

\section{DESCRIPTION OF THE STUDY SITE}

Mida Creek or Watamu Marine National Reserve $\left(3^{\circ} 20^{\prime} \mathrm{S}\right.$, $\left.40^{\circ} 00^{\prime} \mathrm{E}\right)$ is situated $100 \mathrm{~km}$ north of Mombasa in Kilifi district. The reserve was established in 1968, contains natural elements such as mangroves, coral reefs, and mud flats and is a sanctuary for shorebird populations (29). Seven of the 9 mangrove species described in Kenya (2) are found in Mida, and occupy a total area of 1746 ha $(30,31)$. The dominant species are Rhizophora mucronata Lamk. (Rhizophoraceae), Ceriops tagal (Perr.) C.B. Robinson (Rhizophoraceae) and Avicennia marina (Forsk.) Vierh. (Avicenniaceae). The nomenclature is according to Tomlinson (32).

There is no obvious zonation that is displayed by the dominant mangrove species in Mida. A. marina and Lumnitzera racemosa Willd. occupy the landward zone, whereas mostly a C. tagal and R. mucronata mosaic covers the middle zone. Wherever present, Sonneratia alba $\mathrm{Sm}$. occupies the seaward margin, but is replaced by tall A. marina and R. mucronata along small creeks.

The mangroves of Mida Creek are separated naturally by the main creek and the 2 areas are named according to the nearby local villages or islands : Kirepwe and Uyombo (Fig. 1). In the framework of this study these 2 areas were sampled separately and compared. Kirepwe covers the eastern side of the creek and includes mangroves near the villages of Sita, Dabaso and Dongokundu. In the area of the forest approaching Sita seaward (Fig. 1), trees attained a height of $20 \mathrm{~m}$ and diameters above 18 $\mathrm{cm}$. There are 573 ha of mangroves in Kirepwe. Uyombo, on the western side of the creek, stretches between the villages of Uyombo and Majaoni. Because of a large intertidal area, there is a marked difference in the vegetation structure of the seaward and the landward forest in Uyombo ( $c f .22)$. The landward forest is mostly dwarf A. marina while the seaward forests consists of tall R. mucronata. The total mangrove cover in Uyombo is 1172 ha.

The floristic composition of mangroves of Mida has been described by Gang and Agatsiva (30). The forest resembles the fringing mangroves described by Lugo and Snedaker (33), with incoming and retreating tidal velocities that are low and the dense, well-developed prop roots that accumulate large stocks of debris. The forest plays an important role as life support for the Watamu Marine National Reserve (34). This is in addition 
to the profound ecological benefits reportedly derived from mangroves such as coastal stabilization (35), filtration of land runoff and flood control (36).

\section{MATERIALS AND METHODS}

A stratified sampling technique was used to sample mangroves of Mida. The locations of transect lines were determined by an initial reconnaissance and examination of medium-scale (1:25 000) panchromatic aerial photographs of the survey area. Belt transects of 10-m width were established both perpendicular and parallel to the creek across the entire forest, in such a way that they represented as good as possible the general mangrove forest of Mida (Fig. 1). Vegetation sampling was carried out within $100 \mathrm{~m}^{2}$ quadrats, that were regularly laid along the transects. A total of 60 quadrats were studied in Uyombo and 31 in Kirepwe.

Within each quadrat individual trees greater than $2.5 \mathrm{~cm}$ butt diameter were identified and counted. Vegetation measurements included tree height and stem diameter at $130 \mathrm{~cm}$ aboveground $\left(D_{130}\right.$ sensu Brokaw and Thompson, 37), exceptions to this rule are described below, from which were derived tree basal area, species density and frequency $(11,38)$. The ecological importance of each species (39) was calculated by summing its relative density, relative frequency and relative dominance (11). The complexity indices of the forests (in a 0.1 ha plot) were obtained as the product of number of species, basal area $\left(\mathrm{m}^{2} / 0.1 \mathrm{ha}\right)$, maximum tree height $(\mathrm{m})$ and number of stems/0.1 ha, $\times 10^{-3}(10)$. Stems with diameters below $2.5 \mathrm{~cm}$ were considered in the category "juveniles".

Tree heights were measured in meters using a Suunto $^{\mathrm{TM}}$ hypsometer, whereas stem diameter was measured in centimeters using a forest calliper. For Rhizophora, stem diameters were measured $30 \mathrm{~cm}$ above the highest prop roots, whereas for Avicennia, when the stem forked below $130 \mathrm{~cm}$, individual 'branches' in a clump were treated as separate stems. A total of $6275 \mathrm{~m}^{2}$ (in 60 quadrats) and $3100 \mathrm{~m}^{2}$ (in 31 quadrats) were sampled in Uyombo and Kirepwe, respectively.

Information on the composition and distribution pattern of natural regeneration was obtained using the method of Linear Regeneration Sampling (40). In $5 \times 5 \mathrm{~m}^{2}$ subplots (within the main $10 \times 10 \mathrm{~m}^{2}$ quadrats), occurrence of juveniles of different species was recorded and grouped according to their height classes. Seedlings less than $40 \mathrm{~cm}$ in height were classified as regeneration class I (RCI). Saplings between 40 and $150 \mathrm{~cm}$ height were classified as RCII, while RCIII was for all small trees with heights greater than $1.5 \mathrm{~m}$ but less than $3.0 \mathrm{~m}$.

The analysis of spatial pattern of trees and juveniles in the field was carried out inside $10 \times 10 \mathrm{~m}^{2}$ plots along transects. The measure of dispersion used was Morisita's Index (41), the application of which is described in Greig-Smith (42). Morisita's Index $\mathrm{I}_{\mathrm{o}}$ is:

$$
I_{\mathrm{o}}=q \sum_{i=1}^{q} \frac{n_{i}\left(n_{i}-1\right)}{N(N-1)}
$$

Where, $q$ is the number of quadrats, $n_{i}$ is the number of individuals per species in the $i$ th plot, and $\mathrm{N}$ is the total number of individuals in all $q$ quadrats. If $\mathrm{I}_{\mathrm{o}}>1$, the population is clustered, if $\mathrm{I}_{\mathrm{o}}=1$, the population is randomly dispersed and if $I_{0}<1$, the population is evenly dispersed.

\section{DATA TREATMENT}

All data analysis and graphical presentation were obtained with the IBM compatible STATISTICA 5.5 program. One-way ANOVA was performed on stocking densities of different size classes, which we assume as a measure of age.

The stand densities were harmonized using De Liocourt's negative exponential model (43). According to the model, the

Figure 1. Vegetation map of Mida Creek, based on aerial photography and ground truthing. The straight black lines across the vegetation show the position of the belt transects. The legend shows the spatial quantification of the image objects. Quantification of the vegetation based on ground truth data is indicated in Tables 1 to 4.

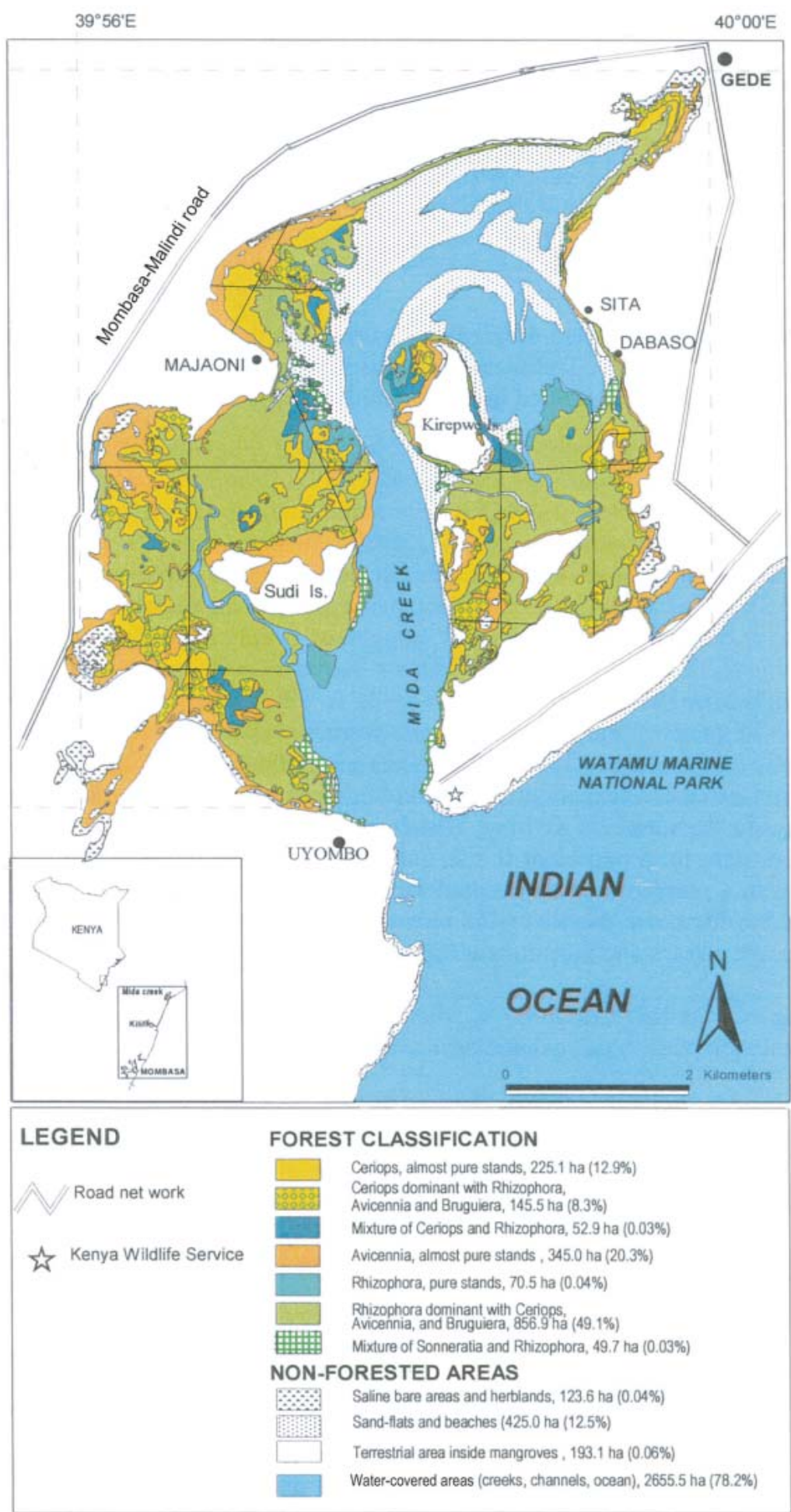


ratio between the numbers of trees in successive diameter classes of uneven-aged stand is roughly constant for a particular forest, but varies from one forest to another. This has been confirmed in a number of uneven-aged forests throughout the world (see e.g. 43 and the literature therein). De Liocourt's model applies particularly in mixed forests where the size classes and recruitment by natural regeneration are continuous.

Supposing we take this ratio to be q, then the number of trees in successive diameter classes is represented by a descending geometric sequence of the form:

$\mathrm{aq}^{\mathrm{n}}, \mathrm{aq}^{\mathrm{n}-1}, \mathrm{aq}^{\mathrm{n}-2}, \mathrm{aq}^{\mathrm{n}-3}, \ldots \ldots . . \mathrm{aq}^{3}, \mathrm{aq}^{2}, \mathrm{aq}^{1}, \mathrm{a}$

where $\mathrm{a}$ is the number of trees in the largest size class of interest and $\mathrm{n}$ is the number of classes.

For such a geometric series, if the logarithm of the frequency

\begin{tabular}{|c|c|c|c|c|c|}
\hline \multirow{2}{*}{$\begin{array}{l}\text { Forest } \\
\text { block }\end{array}$} & \multirow[b]{2}{*}{ Species } & \multirow[b]{2}{*}{ Dominance } & \multicolumn{2}{|c|}{ Relative values (\%) } & \multirow[b]{2}{*}{ I.V. } \\
\hline & & & Density & Frequency & \\
\hline \multirow[t]{6}{*}{ Uyombo } & R. mucronata & 64.77 & 27.36 & 61.67 & 153.80 \\
\hline & C. tagal & 37.61 & 56.74 & 78.33 & 172.68 \\
\hline & A. marina & 34.47 & 11.97 & 21.67 & 68.11 \\
\hline & B. gymnorrhiza & 20.48 & 3.33 & 30.00 & 53.81 \\
\hline & $X$. granatum & 1.26 & 0.30 & 1.67 & 2.23 \\
\hline & L. racemosa & 0.91 & 0.30 & 1.67 & 2.88 \\
\hline \multirow[t]{6}{*}{ Kirepwe } & R. mucronata & 40.97 & 45.55 & 74.19 & 160.71 \\
\hline & C. tagal & 12.89 & 33.42 & 83.87 & 130.18 \\
\hline & A. marina & 19.66 & 11.59 & 29.03 & 60.28 \\
\hline & B. gymnorrhiza & 20.90 & 7.01 & 38.71 & 66.62 \\
\hline & X. granatum & 1.42 & 0.81 & 6.45 & 8.68 \\
\hline & S. alba & 4.14 & 1.62 & 2.23 & 7.99 \\
\hline \multicolumn{6}{|c|}{$\begin{array}{l}\text { (Total number of plots: Uyombo }=60 \text { (total area }=6275 \mathrm{~m}^{2} \text { ), Kirepwe }=31 \\
\text { (total area }=3100 \mathrm{~m}^{2} \text { ). Number of individuals encountered: Uyombo }=994 \text {, } \\
\text { Kirepwe }=331 \text { ). }\end{array}$} \\
\hline
\end{tabular}

in successive classes is plotted against size class, the distribution can be represented as an exponential curve of the form:

$y=k e^{-a x}$

where; $y$ is the number of trees in diameter class $x$; $e$ is the base of natural $\log (2.718)$ while $k$ and $a$ are constants.

The constants $k$ and $a$ in the equation above vary between forests and with site. Constant $k$ reflects the occurrence of seedling regeneration and tends to be large in forests containing prolific seed-bearing tree species while $a$ determines the relative frequencies of successive diameter classes . A high $a$ is associated with high mortality between classes and is likely to occur in stands comprising light demanding (shade intolerant) tree species.

The nature of the future forest was derived from the present forest by fitting exponential models to the size-class structures and comparing the results at a 0.05 significant level. Each class interval was considered to be independent and thus included as within-factor repeated measure variable during the analysis. A chi-square test was used to analyze differences in juvenile densities among the study sites.

\section{RESULTS}

\section{Floristic Composition}

Table 1 shows the composition of mangrove forests in Mida. Based on the species' importance values, $R$. mucronata and $C$. tagal were the principle species at Uyombo and Kirepwe, respectively. Relative dominance, density, frequency and importance values of these species are shown in Table 1.

\section{Stocking Density}

Table 2 give vegetation inventories for Mida Creek mangroves.

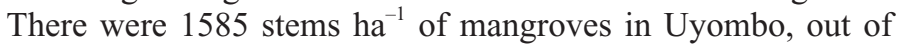

Table 2. Stand table for the mangrove forest of Mida Creek. Values in parentheses indicate percentages of the total in a column.

Utilization class (butt diameter in $\mathrm{cm}$ )

\begin{tabular}{|c|c|c|c|c|c|c|c|c|}
\hline Station & Species & $\leq 6.0$ & $6.1-9.0$ & $9.1-13.0$ & $13.1-20.0$ & $20.1-35.0$ & $>35.0$ & $\begin{array}{r}\text { Density } \\
\left(\text { Stems ha }{ }^{-1}\right)\end{array}$ \\
\hline \multirow[t]{8}{*}{ Uyombo } & A. mar & $\begin{array}{r}61 \\
(32.11)\end{array}$ & $\begin{array}{r}28 \\
(14.74)\end{array}$ & $\begin{array}{r}37 \\
(19.47)\end{array}$ & $\begin{array}{r}45 \\
(2368)\end{array}$ & $\begin{array}{r}16 \\
(8.42)\end{array}$ & $\begin{array}{r}3 \\
(158)\end{array}$ & $\begin{array}{r}190 \\
(1199)\end{array}$ \\
\hline & B. gym & $\begin{array}{r}17 \\
17\end{array}$ & 3 & 2 & $\begin{array}{r}10 \\
18\end{array}$ & 18 & 3 & $\begin{array}{r}53 \\
\end{array}$ \\
\hline & C. tag & $\begin{array}{r}(32.08) \\
682\end{array}$ & $\begin{array}{r}(5.66) \\
93\end{array}$ & $\begin{array}{r}(3.77) \\
76\end{array}$ & $\begin{array}{r}(18.87) \\
46\end{array}$ & $\begin{array}{r}(33.96) \\
2\end{array}$ & $\begin{array}{r}(5.66) \\
-\end{array}$ & $\begin{array}{r}(3.34) \\
899\end{array}$ \\
\hline & L. rac & $\begin{array}{r}(75.86) \\
-\end{array}$ & $\begin{array}{r}(10.34) \\
-\end{array}$ & $\begin{array}{r}(8.45) \\
3\end{array}$ & (5.12) & $(0.22)$ & - & $\begin{array}{r}(56.72) \\
5\end{array}$ \\
\hline & & & & $(60.00)$ & $(40.00)$ & & & $(0.32)$ \\
\hline & R. muc & $\begin{array}{r}135 \\
(31.18)\end{array}$ & $\begin{array}{r}81 \\
(18.71)\end{array}$ & $\begin{array}{r}76 \\
(17.78)\end{array}$ & $\begin{array}{r}100 \\
(23.09)\end{array}$ & $\begin{array}{r}38 \\
(8.98)\end{array}$ & $\begin{array}{r}2 \\
(0.46)\end{array}$ & $\begin{array}{r}433 \\
(27.32)\end{array}$ \\
\hline & X. gra & - & $\begin{array}{r}2 \\
(40.00)\end{array}$ & - & $\begin{array}{r}1 \\
(20.00)\end{array}$ & 2 & $(40.00)$ & $\begin{array}{r}5 \\
(0.32)\end{array}$ \\
\hline & Total & $\begin{array}{r}895 \\
(56.47)\end{array}$ & $\begin{array}{r}207 \\
(13.06)\end{array}$ & $\begin{array}{r}195 \\
(12.30)\end{array}$ & $\begin{array}{r}204 \\
(12.87)\end{array}$ & $\begin{array}{r}76 \\
(4.80)\end{array}$ & $\begin{array}{r}8 \\
(0.51)\end{array}$ & 1,585 \\
\hline \multirow[t]{7}{*}{ Kirepwe } & & $\begin{array}{r}6 \\
(4.32)\end{array}$ & $\begin{array}{r}17 \\
(13.67)\end{array}$ & $\begin{array}{r}16 \\
(12.23)\end{array}$ & $\begin{array}{r}56 \\
(40.29)\end{array}$ & $\begin{array}{r}35 \\
(25.18)\end{array}$ & $\begin{array}{r}6 \\
(4.32)\end{array}$ & $\begin{array}{r}139 \\
(11.61)\end{array}$ \\
\hline & B. $g y m$ & $\begin{array}{r}16 \\
(1905)\end{array}$ & $\begin{array}{r}13 \\
(15.48)\end{array}$ & $\begin{array}{r}3 \\
(357)\end{array}$ & $\begin{array}{r}16 \\
(1905)\end{array}$ & $\begin{array}{r}26 \\
(30.95)\end{array}$ & $\begin{array}{r}10 \\
(1190)\end{array}$ & $\begin{array}{r}84 \\
(7.02)\end{array}$ \\
\hline & C. tag & $\begin{array}{r}219 \\
(5475)\end{array}$ & $\begin{array}{r}55 \\
(1375)\end{array}$ & $\begin{array}{r}48 \\
(12,0)\end{array}$ & $\begin{array}{r}65 \\
(16.25)\end{array}$ & $\begin{array}{r}10 \\
1250)\end{array}$ & $\begin{array}{r}3 \\
(075)\end{array}$ & $\begin{array}{r}400 \\
(3342)\end{array}$ \\
\hline & R. muc & $\begin{array}{r}126 \\
(23.08)\end{array}$ & $\begin{array}{r}26 \\
(4.76)\end{array}$ & $\begin{array}{r}90 \\
(16.48)\end{array}$ & $\begin{array}{r}239 \\
(43.77)\end{array}$ & $\begin{array}{r}65 \\
(11.90)\end{array}$ & - & $\begin{array}{r}545 \\
(45.53)\end{array}$ \\
\hline & S. $a l b$ & - & - & - & $\begin{array}{r}3 \\
(15.79)\end{array}$ & $\begin{array}{r}16 \\
(84.21)\end{array}$ & - & $\begin{array}{r}19 \\
(1.59)\end{array}$ \\
\hline & X. gra & - & - & - & $\begin{array}{r}6 \\
(66.67)\end{array}$ & $\begin{array}{r}3 \\
(33.33)\end{array}$ & - & $\begin{array}{r}10 \\
(0.84)\end{array}$ \\
\hline & Total & $\begin{array}{r}367 \\
(30.66)\end{array}$ & $\begin{array}{r}113 \\
(9.44)\end{array}$ & $\begin{array}{r}158 \\
(13.20)\end{array}$ & $\begin{array}{r}385 \\
(32.16)\end{array}$ & $\begin{array}{r}155 \\
(12.95)\end{array}$ & $\begin{array}{r}19 \\
(1.59)\end{array}$ & 1,197 \\
\hline
\end{tabular}

A. mar = Avicennia marina; B. gym = Bruguiera gymnorrhiza; $C$. tag = Ceriops tagal; L. rac = Lumnitzera racemosa; $R$. muc = Rhizophora mucronata; $S$. alb = Sonneratia alba; X. gra = Xylocarpus granatum

Total number of plots: Uyombo $=60$, Kirepwe =31; number of individuals encountered: Uyombo =994, Kirepwe = 331. 
which $56.7 \%$ were Ceriops and $27.3 \%$ Rhizophora. The rest comprised Avicennia (12.0\%), Bruguiera (3.3\%), Lumnitzera $(0.3 \%)$ and Xylocarpus granatum König (0.3\%). Stem density in Kirepwe was 1197 individuals ha ${ }^{-1}$ (Table 2). The variation in complexity index between Uyombo and Kirepwe is evident (Table 3). Complexity indices were higher in Uyombo than Kirepwe for stems less than $10 \mathrm{~cm}$ diameter.

Figure 2 shows scattergrams of heights against stem diameters of mangrove forests in Mida Creek. There was a significant difference in height $\left(\mathrm{F}_{(1,1363)}=291.1 ; \mathrm{p}=0.0001\right)$ and stem diameter $\left(\mathrm{F}_{(1,1363)}=120.3 ; \mathrm{p}=0.0001\right)$ between Kirepwe and Uyombo mangroves. Fifty percent $(50 \%)$ of the Rhizophora in Kirepwe had a stem diameter of 12.0-20.0 cm (height: 7.5-13.0 m). Though Kirepwe station had more straight poles than Uyombo, the general quality of the standing wood quantity in the two locations did not show a significant difference $\left(\mathrm{F}_{(1,1364)}=1,017\right.$; $\mathrm{p}=0.3135$.

\section{Forest Revegetation}

There were large differences between quadrats in the densities and sizes of juveniles (Table 4). However, based on the total number of saplings, there was no significant difference $\left(\mathrm{F}_{(1,163 ; \alpha}\right.$ $=0.05), p>0.05)$ in the density of juveniles between Uyombo and Kirepwe (Fig. 3). The densities of established juveniles (RCII

\section{Kirepwe}

Figure 2. Heightdiameter distribution of mangrove forests in Mida Creek: (b)

Rhizophora, and (c) Ceriops. The box-plots display percentile distribution in each case. The extremities of the plot correspond to the maximum and minimum observed values in the data set. The ends of the boxes are positioned at the $25 \%$ and $75 \%$ percentiles of the data set.
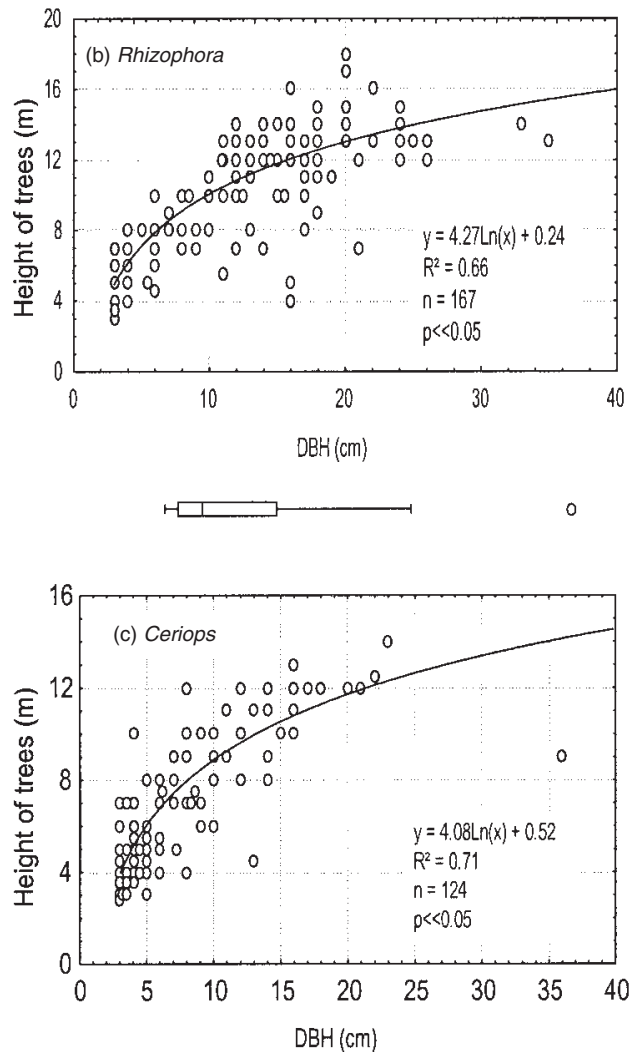

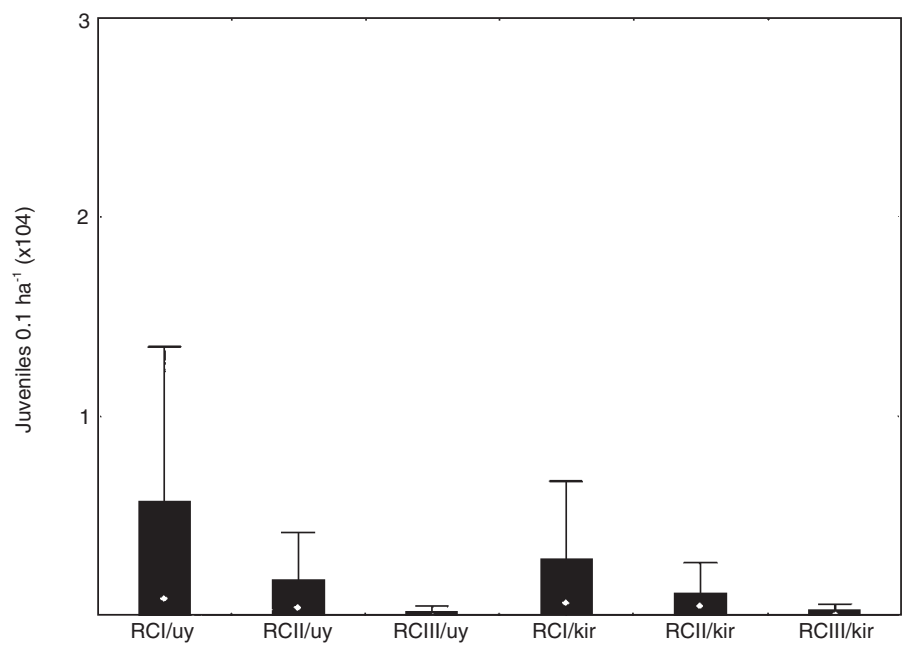

Figure 3. Box-plot display of mangrove saplings in Uyombo (uy) and Kirepwe (kir) stations of Mida Creek. The ends of the box are positioned at the $75 \%$ percentiles of the data set.
Uyombo
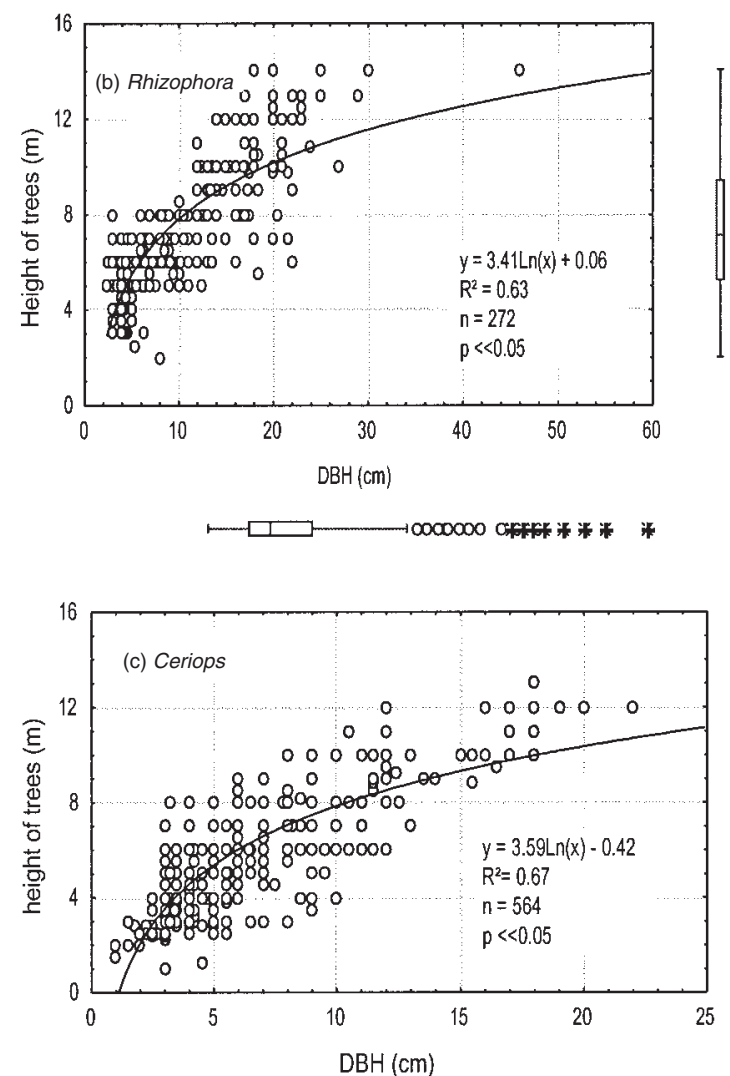

Table 3. Summary of the structural characteristics of Mida mangroves.

Station

Uyombo

Kirepwe

Diameter class $(\mathrm{cm})$

\begin{tabular}{llll}
\hline$<5$ & $5-10 \quad 10-15$ & $>15$
\end{tabular}

$<5 \quad 5-10 \quad 10-15 \quad>15$

3. No. of species

4. Stem density ha

5. Mean height $(m)$

6. Basal area $\left(\mathrm{m}^{2} \mathrm{ha}^{-1}\right)$

$\begin{array}{rr}4 & \\ 777 & 373 \\ 4.3 & 6 \\ 0.89 & 1.70\end{array}$

$\begin{array}{rrr}5 & 5 & 6\end{array}$

$\begin{array}{rr}5 & 6 \\ 195 & 234 \\ 8.1 & 10.4\end{array}$

$\begin{array}{rrr}6.2 & 8.1 & 10.4\end{array}$

$\begin{array}{lll}1.70 & 2.38 & 10.87\end{array}$

* The complexity index C.I. equals the product of (3), (4), (5) and (6) divided by $10^{5}(10)$ 
and RCIII) were 50158 and 22723 saplings ha ${ }^{-1}$ in Uyombo and Kirepwe, respectively (Table 4). Most of the juveniles in Uyombo (85.4\%) and Kirepwe (51.4\%) were Ceriops. Examination of dispersion pattern showed a close to uniform patterns $\left(I_{0}<<1\right)$ of adult trees but a tendency to random distribution $\left(I_{0}\right.$ =1) for juveniles (Fig. 4).

\section{DISCUSSION}

Mangrove forests in Mida Creek are not pristine. All sites visited during this study had visibly been subjected to human disturbance of varying magnitude, over the last 20-30 years (1). These activities have an accumulated effect on the current structure and regeneration of the forest. The high complexity index recorded in the mangrove forests of Kirepwe indicate especially the high basal area and canopy height in $\mathrm{Ki}$ repwe forests as compared to Uyombo (Table 3). The variation in complexity indices between the 2 locations can also be argued in the light of human pressure. The close proximity of human settlements to mangroves of Uyombo, and the fact that people from across the creek travel to this area to cut trees (3), results in higher consumptive wood extraction from the forest, which in turn is reflected in diminished mangrove poles of mazio and boriti sizes (butt diameter range: $8.0-$ $13 \mathrm{~cm}$ ) (Fig. 2). In the less accessible areas of Uyombo, however, there were more stems in the larger diameter classes, taller vegetation and a higher stem density (31).

The structural characteristics of Mida mangroves are given in Table 2. One observation that could be deduced from the stand table data is that stand density is lower for large trees, which is to be expected. However, the rela- tion is not straightforward and when put into size-frequency diagrams it is not possible to obtain a simple correlation between the factors (Fig. 5). This is an indication of man-induced pressure in the forest. Theoretically, in an uneven-aged forest there is a normal series of age-gradations, depicted by the reversed Jcurve. The fact that such a relationship was not obvious in some stands of Mida could be indicative for a human influenced environment and the normal relationship is disturbed. It also indicates that the disturbance of the forest is according to direct needs by the people without a particular harvesting plan and therefore the spatial distribution of different size classes becomes haphazard, whereas the graphical frequency distribution becomes highly selective. This is in line with the statements that local people give when interviewed about their harvesting practices (3). On

\begin{tabular}{|c|c|c|c|c|c|}
\hline \multirow[b]{2}{*}{ Station } & \multirow[b]{2}{*}{ Species } & \multicolumn{3}{|c|}{ Regeneration classes } & \multirow[b]{2}{*}{ Total ha ${ }^{-1}$} \\
\hline & & $\begin{array}{c}\mathrm{RCl} \\
0-40 \mathrm{~cm}\end{array}$ & $\begin{array}{c}\mathrm{RCll} \\
40.1-150.0 \mathrm{~cm}\end{array}$ & $\begin{array}{c}\text { RCIII } \\
150.1-300 \mathrm{~cm}\end{array}$ & \\
\hline \multirow[t]{3}{*}{ Uyombo } & $\begin{array}{l}\text { A. marina } \\
\text { B. gymnorrhiza } \\
\text { C. tagal } \\
\text { L. racemosa }\end{array}$ & $\begin{array}{r}15751\left(952.0^{*}\right. \\
(95.1) \\
2155(63.1 \\
(78.2) \\
155192 \pm 753.1 \\
(77.2) \\
-\end{array}$ & 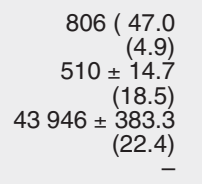 & $\begin{array}{r}5 \pm 0.6 \\
(0.0) \\
92 \pm 3.3 \\
(3.3) \\
728 \pm 3.3 \\
(0.4) \\
2\end{array}$ & $\begin{array}{r}16562 \\
(7.1) \\
2757 \\
(1.2) \\
199866 \\
(85.6) \\
2\end{array}$ \\
\hline & R. mucronata & $\begin{array}{r}10346 \pm 54.6 \\
(71.8)\end{array}$ & $\begin{array}{r}3924 \pm 20.7 \\
(27.2)\end{array}$ & $\begin{array}{r}(100) \\
145 \pm 0.8 \\
(1.0)\end{array}$ & $\begin{array}{r}(0.0) \\
14315 \\
(6.1)\end{array}$ \\
\hline & Total & $\begin{array}{r}183344 \\
(78.5)\end{array}$ & $\begin{array}{r}49186 \\
(21.1)\end{array}$ & $\begin{array}{r}972 \\
(0.4)\end{array}$ & 233502 \\
\hline \multirow[t]{2}{*}{ Kirepwe } & $\begin{array}{l}\text { A. marina } \\
\text { B. gymnorrhiza } \\
\text { C. tagal } \\
\text { R. mucronata }\end{array}$ & $\begin{array}{r}903 \pm 1,223.0 \\
(85.3) \\
426 \pm 39.1 \\
(88.6) \\
38848 \pm 611.4 \\
(75.5) \\
37223 \pm 668.4 \\
(79.0)\end{array}$ & $\begin{array}{r}155 \pm 14.7 \\
(14.7) \\
39 \pm 5.2 \\
(8.1) \\
11819 \pm 143.2 \\
(23.0) \\
9465 \pm 143.4 \\
(20.1)\end{array}$ & $\begin{array}{r}- \\
16 \pm 3.2 \\
(3.3) \\
768 \pm 15.9 \\
(1.5) \\
461 \pm 5.4 \\
(1.0)\end{array}$ & $\begin{array}{r}1058 \\
(1.1) \\
481 \\
(0.5) \\
51435 \\
(51.4) \\
47149 \\
(47.1)\end{array}$ \\
\hline & Total & $\begin{array}{r}77400 \\
(77.3)\end{array}$ & $\begin{array}{r}21478 \\
(24.5)\end{array}$ & $\begin{array}{l}1245 \\
(1.2)\end{array}$ & 100123 \\
\hline${ }^{*}$ mean $=$ & & & & & \\
\hline
\end{tabular}

Figure 4. Values of Morisita's Indices along transects for the commercial mangrove species in Mida Creek. Both the adult trees and juveniles are evenly dispersed, $I_{0}<0$.
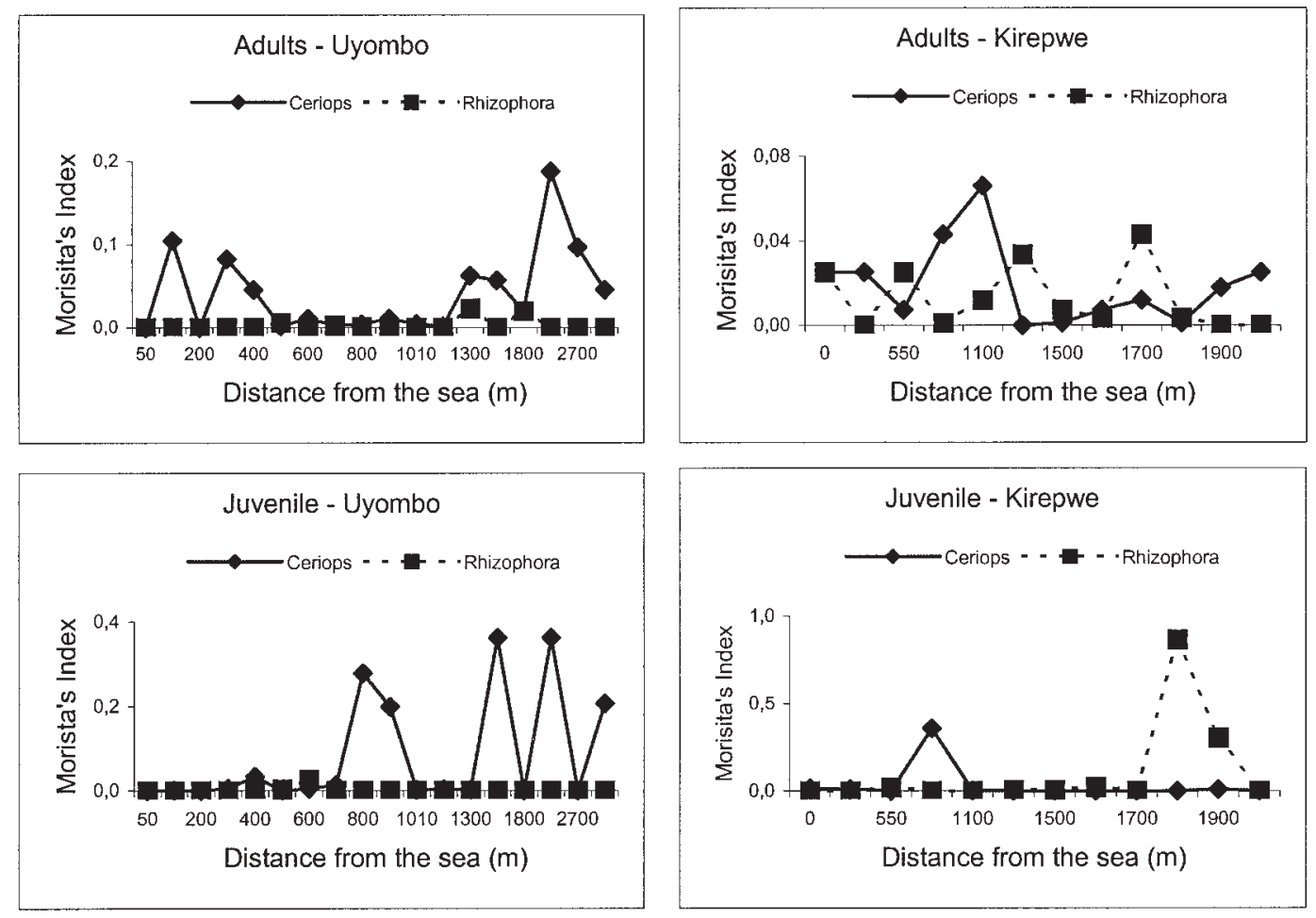
the general assumption that the sizes of trees express age, we can use the density curves obtained in this study (Fig. 5) to predict the composition of the future managed forest. This can be done through 2 approaches. Firstly, we must harmonise the irregularities in the size-class distribution, and the second step will be to reduce stem density per class by allowing multiple use of mangrove wood, e.g. for charcoal or fuelwood production. The present mangrove management in Kenya prohibits the use of mangrove wood products for industrial fuelwood or charcoal, but the question remains to what extent the law is enforced. Dahdouh-Guebas et al. (3) illustrated how vicious the situation may be under a governmental ban to cut mangrove wood. A number of alternatives to mangrove cutting have been suggested (44), but it seems that people receive few alternatives in return from the government.

A forest managed on clearcutting silviculture practices and a sustained annual yields basis assumes a normal distribution of size and classes (45). The forest in Mida is akin to that of a selection forest (46). Selective removal of the small-sized poles by the cutters and the consequential creation of gaps in the forest canopy stimulate regeneration that approximates selection forest working. However, this natural regeneration is not necessarily of the same species harvested. Field observation showed that, in a mixed stand of Ceriops and Rhizophora there was a tendency for natural regeneration to favor Ceriops, irrespective of the harvested crop.

The observed pattern can be illustrated with respect to the ratios of adult and young trees (RCIII) of $R$. mucronata and $C$. tagal which is important to highlight (Table 3 and 4). In Uyombo, the site that has been under a stronger anthropogenic influence, the density of adult trees is higher for Ceriops than for Rhizophora (899 stems ha ${ }^{-1}$ and 433 stems ha $^{-1}$, respectively) and the same is true for the RCIII young trees (728 Ceriops

Figure 5. Size class distribution of mangrove forests in Mida Creek. A high ' $k$ ' value in the stand curve $y=k^{-a x}$ for Uyombo reflects the occurrence of sporadic natural regeneration in the forest.
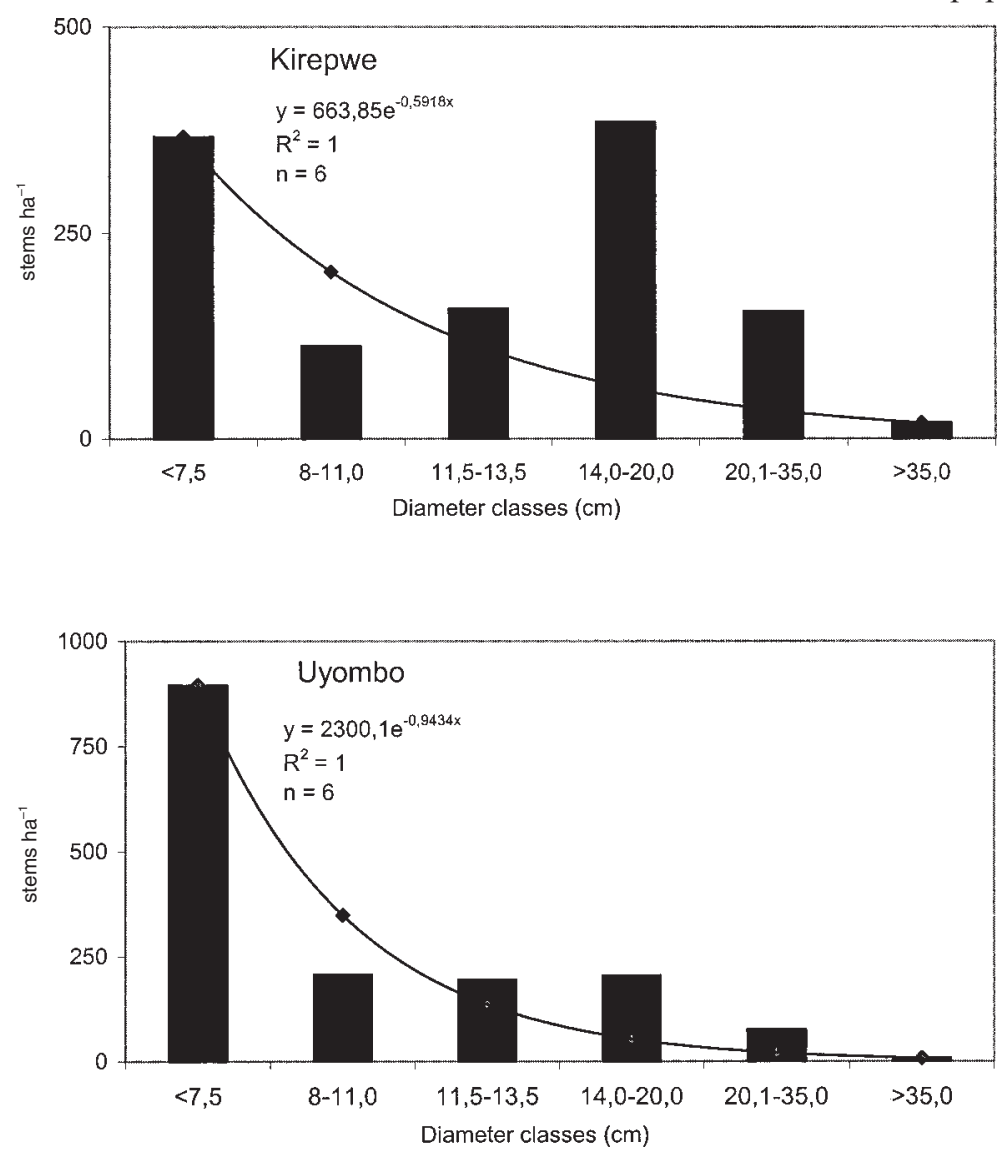

$\mathrm{ha}^{-1}$ compared to 145 Rhizophora $\mathrm{ha}^{-1}$ ). In Kirepwe, the Rhizophora dominated forest natural to Mida Creek can still be observed in the ratio of the adult trees (545 Rhizophora ha $^{-1}$ compared to 145 Ceriops $\mathrm{ha}^{-1}$ ), but the young mangrove population has already shifted to a domination by Ceriops (768 Ceriops $\mathrm{ha}^{-1}$ compared to 461 Rhizophora $\mathrm{ha}^{-1}$ ). Although we cannot estimate what proportion of the young Ceriops trees will survive, we are dealing with a regeneration class that may be indicative for a transition in the Kirepwe area, similarly to the one that occurred in the Uyombo area.

This adds to silviculture problems because the desirable Rhizophora forest is slowly giving way to the inferior Ceriops forest from the local economical point of view (6). Whether the Ceriops forest maintains its position in further development or succession, and whether it will play the same ecological role, cannot be assessed with the current data.

\section{CONCLUSIONS}

The potential yield of future mangrove forest in Mida can be gauged by an evaluation of the present stand tables. The present inventory revealed that the existing mangrove forests in Uyombo and Kirepwe have standing densities of 1585 and 1197 stems $\mathrm{ha}^{-1}$, respectively (Table 2). This is considered to be high, considering that mangroves of Mida are not pristine. In Matang, Malaysia, the average density for a 30-yr old stand of $R$. apiculata is 1343 trees ha ${ }^{-1}$ with an average volume of $153 \mathrm{~m}^{3} \mathrm{ha}^{-1}$ (47). In Ranong, Indonesia, where some of the best-managed mangroves in the world are located, an average density of 812 trees $\mathrm{ha}^{-1}$ and a volume of $226 \mathrm{~m}^{3} \mathrm{ha}^{-1}$ have been reported (48). Chong (45) estimated an annual harvest of $1185 \mathrm{~m}^{3} \mathrm{yr}^{-1}$ in a $25-\mathrm{yr}$ rotation from Térraba-Sierpe of Costa Rica that contained a stocking of 769 trees ha ${ }^{-1}$ (or $281 \mathrm{~m}^{3} \mathrm{ha}^{-1}$ ). Mida Creek has probably one of the most productive mangrove forests in Kenya.

The sapling density varied greatly between localities but was on average very high, which implies adequate recruitment in most localities (Table 4). The near randomness of the sapling population may be the result of redistribution of propagules by tidal action $(19,49)$, which either means that everywhere the right (initial) ecological conditions for the species occur, or that the ecological settings are irrelevant. To assess effective stocking all regeneration classes must be considered. Saplings of RCII/III have higher incremental volume, older mortality, lower mortality, and contribute more significantly towards final crop stocking (46). While working on mangroves of Costa Rica, Chong (45) formulated 'equivalent regeneration values' for different regeneration classes (RCI: RCII: RCIII). A regeneration ratio of 6:3:1 was found to be an effective stocking rate for saplings. In the present study, the 'equivalent regeneration values' for Uyombo and Kirepwe were calculated as $86: 51: 1$ and $62: 17: 1$, respectively. If the management objectives for the mangrove of Mida Creek is to have a dense forest cover $(>60 \%)$, irrespective of species, then there will be no need to replant degraded mangrove, areas since the present study shows that Mida's mangrove can recover itself. However, if the management objective is to promote sustainable production of the economically superior Rhizophora, the sacrificial removal of excess Ceriops may be necessary.

The major outcome of this paper is that unmanaged but exploited mangroves do not necessarily disappear, but change qualitatively as described above. It indicates that small human communities themselves apparently do not sustainably manage the mangrove. The effects of the shifts in dominant species on the ecological function of the mangrove cannot be estimated yet, but the economical function of the mangrove has thus evidently weakened. 

1. Rawlins, S. 1957. The East African Mangrove Trade. Unpublished typescript in the
East Africa Herbarium, NMK, Nairobi.

2. Kokwaro, J.O. 1985. The distribution and economic importance of the mangrove forests of Kenya. J. East Afr. Nat. Hist. Soc. 75, 1-12.

3. Dahdouh-Guebas, F., Mathenge, C., Kairo, J.G. and Koedam, N. 2000. Utilization of Dahdouh-Guebas, F., Mathenge, C., Kairo, J.G. and Koedam, N. 2000. Utilization of
mangrove wood products around Mida Creek (Kenya) among subsistence and commercial users. Econ. Bot. 54, 513-527.

4. Wass, P. (ed.) 1995. Kenya's Indigenous Forests: Status, Management and Conservation. IUCN, Grand, Switzerland, and Cambridge, UK. Xii + 205pp. 2-8317-0292-5.

Abuodha, P.A.W. and Kairo, J.G. 2001. Human-induced stresses on mangrove swamps
along the Kenyan coast. In: Science and the Sustainable Management of Shallow Tropialong the Kenyan coast. In: Science and the Sustainable Management of Shallow Tropical Waters. Harper, D. Boar, R. Everard, M. and Hickley, P. (eds). Hydrobiologia 458. Kluwer Academic Publishers, Dordrecht, The Netherlands, 255-265.

6. Kairo, J.G. 2001. Ecology and Restoration of Mangrove Systems in Kenya. PhD Thesis. Laboratory of Plant Sciences and Nature Management, Free University of Brussels, Belgium. $108 \mathrm{pp}$.

FAO 1993. Conservation and Management of Mangrove, Kenya. Terminal statement prepared for the Government of Kenya. FAO, ROME. FO: TCP/KEN/0051

8. FD and KWS (Forest Department and Kenya Wildlife Service) 1993. National Workshop for Improved Management and Conservation of the Kenyan Mangroves, July 1993 KFMP/KIFCON, Nairobi.

9. Janzen, D.H. 1985. Mangroves: where's the understory? J. Trop. Ecol. 1, 89-92.

10. Holdridge, L.R., Greeke, W.C., Hatheway, W.H., Liang, T. and Tosi, J.A. 1971. For est Environment in Tropical Life Zones. Pergamon Press, N. Y. 747 pp.

11. Cintrón, G. and Schaeffer-Novelli, Y. 1984. Methods for studying mangrove structure. In: The Mangrove Ecosystem: Research Methods. Snedaker, S.C. and Snedaker, J.G. (eds). UNESCO, Paris, France, 91-113.

12. Odum, W.E. and Heald, E.J. 1975. The detritus food web of an estuarine mangrove community. In: Estuarine Research, Cronin, L. (ed.). Academic Press, New York, NY pp. 265-286.

13. Azariah, J., Azariah, H., Gunasekaran, S. and Selvam, V. 1992. Structure and species distribution in Coringa mangrove forest, Godavari Delta, Andhra Pradesh, India. Hydrobiologia 247, 11-16.

14. Lugo, A.E., Gonzalez-Liboy, J.A., Cintrón, B. and Dugger, K. 1978. Structure, productivity, and transpiration of a subtropical dry forest in Puerto Rico. Biotropica 10, 278-291.

15. Pool, D.J., Snedaker, S.C. and Lugo, A.E. 1977. Structure of mangrove forests in Florida, Puerto Rico, Mexico and Costa Rica. Biotropica 9, 195-212.

16. Graham, R.M. 1929. Notes on the mangrove swamps of Kenya. J. East Afr. Nat. Hist. Soc. $36,157-165$

17. Gallin, E., Coppejans, E. and Beeckman, H. 1989. The mangrove vegetation of Gazi bay (Kenya). Bull. Soc. Roy. Bot. Belg. 122, 197-207.

18. Dahdouh-Guebas, F., Kairo, J.G., Jayatissa, L.P., Cannicci, S. and Koedam, N. An ordination study to view past, present and future vegetation structure dynamics in disturbed and undisturbed mangroves forests in Kenya and Sri Lanka. Plant Ecol. (In press).

19. Van Speybroeck, D. 1992. Regeneration strategy of mangroves along the Kenyan coast: A first approach. Hydrobiologia 247, 243-251.

20. Slim, F.J., Hemminga, M.A., Ochieng, C., Jannink, N.T., Cocheret de la Morinière, E. and van der Velde, G. 1997. Leaf litter removal by the snail Terebralia palustris (L.) and Sesarmid crabs in an East African mangrove forest (Gazi Bay, Kenya). J. Exp. Mar. Biol. Ecol. 215, 35-48.

21. Hartnoll, R.G., Cannicci, S., Emmerson, W.D., Fratini, S., Macia, A., Mgaya, Y., Porri, F., Ruwa, R.K., Shunula, J.P., Skov, M.W. and Vannini, M. Geographic trends in mangrove crab abundance in East Africa. Wetlands Ecol. Mgmt. (In press)

22. Dahdouh-Guebas, F., Cannicci, S., Verneirt, M., Kairo, J.G. and Koedam, N. 2002. An exploratory study on grapsid crab zonation in mangrove forests in Kenya. Wetlands Ecol. Mgmt. (In press)

23. Cannicci, S., Dahdouh-Guebas, F., Anyona, D. and Vannini, M. 1996. Natural diet and feeding habits of Thalamita crenata (Decapoda : Portunidae). J. Crust. Biol. 16, 678 683 24. Dahdouh-Guebas, F., Verneirt, M., Tack, J.F. and Koedam, N. 1997. Food preferences
in Neosarmatium meinerti de Man (Decapoda: Sesarminae) and its possible effect on the regeneration of mangroves. Hydrobiologia 347, 83-89.

25. Dahdouh-Guebas, F., Verneirt, M., Tack, J.F., Van Speybroeck D. and Koedam, N. 1998. Propagule predators in Kenyan mangroves and their possible effect on regeneration. Mar. Freshwater Res. 49, 345-350.

26. Dahdouh-Guebas, F., Giuggioli, M., Oluoch, A., Vannini, M. and Cannicci, S. 1999. Feeding habits of non-ocypodid crabs from two mangrove forests of Kenya. Bull. Mar. Sci. 64, 291-297.

27. Hemminga, M.A., Slim, F.J., Kazungu, J., Ganssen, G.M., Nieuwenhuize, J. and Kruyt, N.M. 1994. Carbon outwelling from a mangrove forest with adjacent seagrass beds and coral reefs (Gazi Bay, Kenya). Mar. Ecol. Prog. Ser. 106, 291-301.

28. Middelburg, J.J., Nieuwenhuize, J., Slim, F.J. and Ohowa, B. 1996. Sediment biogeochemistry in an East African mangrove forest (Gazi Bay, Kenya). Biogeochem. 34, 133 155

29. UNEP/IUCN 1988. Coral Reefs of the World, Vol.2: Indian Ocean, Red Sea and Gulf. UNEP Regional Seas Directories and Bibliographies. IUCN, Gland, Switzerland and Cambridge UK/ UNEP Nairobi, Kenya. 290 pp, 36 maps.

30. Gang, P.O. and Agatsiva, J.L. 1992. The current status of mangroves along the Kenyan coast: a case study of Mida Creek mangroves based on remote sensing. Hydrobiologia 247, 29-36.

31. Kairo, J.G. and Gwada, P.O. 1998. Mangroves of Mida Creek, Kenya. In: Biodiversity of Mida Creek: Final Technical Report, Mwatha, G.K., Fondo, E., Uku, J. and Kitheka, J.U. (eds). pp. $150-182$

32. Tomlinson, C.B. 1986. The Botany of Mangroves. Cambridge Tropical Biology Series, Cambridge University Press, Cambridge, New York, U.S

33. Lugo, A.E. and Snedaker, S.C. 1974. The ecology of mangroves. Ann. Rev. Ecol. Syst. $5,39-64$.

34. Gwada, P.O. and Kairo, J.G. 2001. Litter production in three mangrove forests stands of Mida Creek, Kenya. S. Afr. J. Bot. 67, 443-449.

35. Davis, J.H.Jr. 1940. The ecology and geological role of mangroves in Florida. Pap Tortugas Lab. 32, 303-412.

36. Thom, B.G. 1982. Mangrove ecology: a geomorphological perspective. In: Mangrove Ecosystem in Australia, Structure, Function and Management. Clough, B.F. (ed.), Australian National University Press, Canberra, pp. 3-17.

37. Brokaw, N. and Thompson, J. 2000. The H for DBH. Forest Ecol. Mgmt 129, 89-91.

38. Mueller-Dombois, D. and Ellenberg, H. 1974. Aims and Methods of Vegetation Ecology. Wiley and Sons Inc. New York, U.S.A.

9. Curtis, J.T. 1959. The Vegetation of Wisconsin. An Ordination of Plant Communities. University of Wisconsin Press, Madison, Wisconsin, USA.

40. Sukardjo, S. 1987. Natural regeneration status of commercial mangrove species (Rhizophora apiculata and Bruguiera gymnorhiza) in mangrove forests of Tanjung Bungin, Bunyuasin District, South Sumatra. Forest Ecol. Mgmt 20, 233-252.

41. Morisita, M. 1959. Measuring of the dispersion of individuals and analysis of the dis- tribution patterns. Mem. Fac. Sci. Kyushu Univ. Ser. E Biol. 2, 215-235.

2. Greig-Smith, P. 1983. Quantitative Plant Ecology. 3rd edn. Studies in Ecology, 9. Blackwell Publishers, UK. pp. 66-67.

Clutter, J.L., Fortson, J C., Pienaar, L.V., Brister, G.H. and Bailey, R.L. 1983. Timber Management: A Quantitative Approach. John Wiley and Sons. $333 \mathrm{pp}$.

44. Omodei-Zorini, L and Contini, C. 2000. A multicriterion analysis for the sustainable use of natural resources in mangrove ecosystems with the involvement of local community. In: Proc. 4th European Symposium on European Farming and Rural Systems Research and Extension into the Next Millennium, Volos, April 3-7.

45. Chong, P.W. 1988. Proposed Integrated Forest Management Planning and Utilization of Mangrove Resources in the Terraba-Sierpe Reserve, Costa Rica. TCP. FAO, Rome. 6. FAO 1994. Mangrove forest management guidelines. FAO Forestry Paper, 117. Rome, $320 \mathrm{pp}$

7. Haron, H.A.H. 1981. A Working Plan for the Second 30 Year Rotation of the Matang Mangrove Forest Reserve, Perak. Perak State Forestry Department, Ipoh, Malaysia, $115 \mathrm{pp}$.

48. Aksornkoae, S. 1993. Ecology and Management of Mangrove Forests. IUCN, Bangkok, Thailand.

49. Rabinowitz, D. 1978. Early growth of mangrove seedlings in Panama. Biogeography $5,113-133$.

50. We are very grateful to Dirk Van Speybroeck for his advise and support. This work was partly supported by The Netherlands Wetland Program of the Kenya Wildlife Service (KWS), by the European Commission (Contract No. IC18-CT96-0065), the Fund for Collective Fundamental Research (FKFO), the Vrije Universiteit Brussel (VUB, VUBAROS), the Institute for the Promotion of Innovation by Science and Technology in Flanders (IWT), and the Fund for Scientific Research (FWO-Vlaanderen), of which the second author is a Post-doctoral Researcher. We are very grateful to all these people and institutions.

James Gitundu Kairo received a MSc in botany from the University of Nairobi, Kenya and a PhD in sciences from the Vrije Universiteit Brussel, Belgium. He has been working at the Kenya Marine and Fisheries Research Institute for more than 10 years, and is involved in mangrove regeneration and restoration projects for the Kenyan Forestry Department, Word Wide Fund for Nature (WWF), Food and Agricultural Organisation (FAO), and many more. His address: Mangrove System Information Service, Kenya Marine and Fisheries Research Institute (KMFRI), P.O. Box 81651, Mombasa, Kenya. E-mail: jkairo@recoscix.org

Farid Dahdouh-Guebas holds an MSc biology, an MSc human ecology and a PhD sciences from the Vrije Universiteit Brussel. His previous and current research is on tropical coastal ecosystems and includes remote sensing of seagrass distributions, feeding ecology and behavioral ecology of mangrove crabs and ongoing research on mangrove vegetation structure dynamics (using very high resolution remote sensing) and biocomplexity (incl. human factors). His address: Laboratory of General Botany and Nature Management, Mangrove Management Group, Vrije Universiteit Brussel, Pleinlaan 2, B-1050 Brussel, Belgium.

E-mail: fdahdouh@vub.ac.be

Patrick $O$. Gwada is a senior research scientist at the Kenya Marine and Fisheries Research Institute, Mombasa, as well as the Kenyan Coordinator of the Western Indian Ocean Marine

Scientists Association (WIOMSA). He holds a MSc from the University of Ryukyus, Japan, where he specialized in mangrove research. He is currently involved in the coordination of the Seaweed Africa Project Underpinning Sustainable Ecosystem Management of Seaweed Resources in Africa, an EU research project aimed at expanding the applications of the Seaweed Database. His address: Kenya Marine and Fisheries Research Institute (KMFRI), P.O. Box 81651, Mombasa, Kenya.

E-mail: pgwada@recoscix.org

Caroline Ochieng has worked as a research officer at the Kenya Marine and Fisheries Research Institute before moving to Thailand on a mangrove rehabiliation project. She is currently involved in an IUCN project on the environmental management of the River Rufiji Delta in Tanzania. Her address: Department of Botany, University of Dar-Es-Salaam, P.O. Box 35060, Dar-Es-Salaam, Tanzania.

E-mail: aheronl@yahoo.com

Nico Koedam was trained as a biologist and started physioecological research on temperate forest plants. Besides an ecology, biogeography and nature management teaching assignment, he is now heading the research unit Genera Botany and Nature Management of the Vrije Universiteit Brussel, which has major ongoing vegetation research programs (remote sensing and field analysis) on Kenyan, Sri Lankan and Indian mangrove ecosystems (Indian Ocean); a smaller research program was initiated in Mauritanian mangroves (Atlantic Ocean). His address: Laboratory of General Botany and Nature Management, Mangrove Management Group, Vrije Universiteit Brussel, Pleinlaan 2, B-1050 Brussel, Belgium.

E-mail: nikoedam@vub.ac.be 